\title{
Effect of dietary plants on the production of immunoglobulins A in healthy Wistar rats
}

\section{Efeito de plantas dietéticas na produção de imunoglobulinas A em ratos Wistar saudáveis}

\author{
Flávia Imanishi Ruzon-Camargo ${ }^{1}$, Eduardo Vignoto Fernandes ${ }^{2}$, \\ Mayara Bocchi ${ }^{3}$, David Michel de Oliveira ${ }^{4}$, Emerson José \\ Venancio $^{5}$, Raul Jorge Hernan Castro Gómez ${ }^{6}$
}

\begin{abstract}
Introduction: some plants such as turmeric, cinnamon, and okra are known to have therapeutic functions such as antioxidant and anti-inflammatory activity. Furthermore, an immunomodulatory role has been observed in the production of antibodies, in particular immunoglobulin A $(\operatorname{IgA})$, which mediates a variety of protective functions for the organism. Objective: the aim of the present study was to investigate the effect of dietary plants on the production of IgA in healthy Wistar rats. Methods: thus, 48 male Wistar rats of 90 days of age were allocated to four groups. The animals were treated for 14 days with dried turmeric, cinnamon, or okra (50,50, $12.5 \mathrm{mg} /$ day, respectively) in phosphate buffered saline, or with only phosphate buffered saline by gavage. The animals received water and feed ad libitum. Body mass and relative weight ofperitoneal fat, adrenal gland, kidney, spleen, liver and thymus, biochemical parameters, and IgA levels were analyzed. Results: no significant changes were observed in the body mass, relative weight of organs and tissues, and biochemical parameters. An increase in serum IgA levels was observed in animals treated with turmeric or cinnamon. Conclusion: we conclude that the treatment with turmeric and cinnamon increased IgA production. Therefore, our study supports the idea that dietary supplementation with these plants may improve humoral immunity.
\end{abstract}

Keywords: Curcuma; Cinnamomum; Abelmoschus; Antibodies; Medicinal plants.

${ }^{1}$ Doutorado em Ciência de Alimentos pela Universidade Estadual de Londrina (UEL), Londrina, Paraná, Brasil.

${ }^{2}$ Doutorado em Patologia Experimental pela Universidade Estadual de Londrina, Londrina, Paraná, Brasil. Docente na Universidade Federal de Jataí (UFJ), Unidade Acadêmica Especial de Ciências Biológicas, Laboratório de Anatomia Humana e Comparativa, Jataí, Goiás, Brasil.E-mail: eduardovignoto@ufj.edu.br

${ }^{3}$ Doutoranda em Fisiopatologia Clínica e Laboratorial na Universidade Estadual de Londrina, Londrina, Paraná, Brasil.

${ }^{4}$ Doutorado em Alimentos e Nutrição pela Universidade Estadual Paulista "Júlio de Mesquita Filho" (Unesp), Araraquara, São Paulo, Brasil. Professor Adjunto III Classe C da Universidade Federal de Jataí, Unidade Acadêmica de Ciências da Saúde, Departamento de Educação Física, Jataí, Goiás, Brasil.

${ }^{5}$ Doutorado em Biologia Molecular pela Universidade de Brasília (UnB), Distrito Federal, Brasil. Professor Associado da Disciplina de Imunologia do Departamento de Ciências Patológicas da Universidade Estadual de Londrina, Londrina, Paraná, Brasil.

${ }^{6}$ Doutorado em Ciência de Alimentos pela Universidade Estadual de Campinas (Unicamp), Campinas, São Paulo, Brasil. Docente na Universidade Estadual de Londrina, Londrina, Paraná, Brasil. 


\section{Resumo}

Introdução: algumas plantas como a cúrcuma, a canela e o quiabo são conhecidas por apresentar funções terapêuticas, como atividade antioxidante e anti-inflamatória. Além disso, tem sido observado um papel imunomodulador sobre a produção de anticorpos, em especial a imunoglobulina A (IgA), a qual medeia uma variedade de funções protetoras para o organismo. Objetivo: o objetivo do presente estudo foi investigar o efeito de plantas dietéticas na produção de IgA em ratos Wistar saudáveis. Métodos: destarte, 48 ratos machos Wistar com 90 dias de idade foram alocados em quatro grupos. Os animais foram tratados por 14 dias com cúrcuma seca, canela ou quiabo $(50,50,12,5 \mathrm{mg} /$ dia, respectivamente) em solução salina tamponada com fosfato ou apenas solução salina tamponada com fosfato, por gavagem. Os animais receberam água e ração ad libitum. Foram analisados a massa corporal e o peso relativo da gordura peritoneal, glândula adrenal, rim, baço, fígado e timo, parâmetros bioquímicos e níveis de IgA. Resultados: não foram observadas alterações significativas na massa corporal, no peso relativo dos órgãos e tecidos e nos parâmetros bioquímicos. Foi observado aumento dos níveis séricos de IgA nos animais tratados com cúrcuma ou canela. Conclusão: podemos concluir que o tratamento com cúrcuma e canela aumentou a produção de IgA. Portanto, nosso estudo suporta a ideia de que a suplementação alimentar com essas plantas pode melhorar a imunidade humoral.

Palavras-chave: Cúrcuma; Cinnamomum; Abelmoschus; Anticorpos; Plantas medicinais.

\section{Introduction}

The use of plants and their parts as therapeutic agents is a common practice. ${ }^{(1-2)}$ Many have medicinal properties and their application, especially in traditional medicine, is well recognized and established. Although they have some aspects similar to modern drugs, in general, they are less aggressive and safer. ${ }^{(3)}$

Turmeric (Curcuma longa), a member of the Zingiberaceae family, ${ }^{(4-5)}$ is an important spice, which confers color and aroma, in addition to demonstrating medicinal properties, such as antiviral, antioxidant, anti-inflammatory, antibacterial, and antifungal activity, thus presenting a potential for action against various diseases, such as diabetes, allergies, and arthritis. ${ }^{(6-7)}$ Furthermore, for Jagetia and Aggarwal, ${ }^{(8)}$ this substance has been shown to be a potent immunomodulatory agent on $\mathrm{T}$ and $\mathrm{B}$ cells, macrophages, neutrophils, and natural killer and dendritic cells.

Okra (Abelmoschus esculentus), a member of the Malvaceae family, ${ }^{(9)}$ is valued for being a nutritious fruit and abundant in minerals. ${ }^{(10)}$ In traditional Chinese medicine, it is used to promote diuresis and to treat dental diseases and gastric irritations, as reported by Ndjouenkeuetal. ${ }^{(11)}$ Furthermore, it has been shown to be useful in the treatment of inflammation, constipation, and urinary retention. ${ }^{(12)}$

Cinnamon is obtained from the bark of several species of the genus Cinnamomum, Lauraceae family, and is a highly appreciated seasoning for its flavor and health benefits. As a traditional medicinal plant, it is very popular in the treatment of various disorders such as chronic gastric disorders, arthritis, and the common cold. ${ }^{(13)}$ It has anti-ulcer, anti-inflammatory, antioxidant, antimicrobial, and anti-diabetic action and its consumption also provides trace amounts of choline, which helps in acetylcholine synthesis and fat metabolism. ${ }^{(14)}$

The literature has shown that the addition of turmeric, cinnamon, and okra to the diet have positive effects on variables including body mass, blood glucose, lipid profile, and the immune system, such as increased production of immunoglobulin A (IgA). ${ }^{(15-17)}$

Serum IgA was first discovered in $1953^{(18)}$ and mediates a variety of protective functions through interaction with $\mathrm{FcR} \alpha$ receptors on monocytes 
and granulocytes; thereby, immune complexes formed by foreign antigens and $\operatorname{IgA}$ are cleared from the circulation by the phagocytic system without activating the complement system and without causing inflammation. Serum IgA may also play a role in controlling the immune system through its binding to proteins that inhibit neutrophil chemotaxis (e.g., $\alpha$-1-antitrypsin). ${ }^{(19)}$

As mentioned above, studies that assess the action of turmeric, cinnamon, and okra are generally carried out in animals with some type of disease, such as overweight and diabetes, ${ }^{(16)}$ or submitted to a diet rich in fructose, or with hyperlipidemia. ${ }^{(6,20)}$ However, few studies have evaluated the effects of these plants on physiological parameters in healthy animals. ${ }^{(17)}$ Therefore, the aim of the present study was to verify the effect of dietary plants on the production of immunoglobulin A in healthy Wistar rats.

\section{Methods}

\section{Sample preparation}

Dried and powdered turmeric (Curcuma longa) and cinnamon (Cinnamomum spp.), as well as okra fruits (Abelmoschus esculentus) were purchased in the local market of the city of Londrina, Paraná state, Brazil. The okra fruits were sanitized with soap and water and then soaked in bleach (250 ppm. $\mathrm{L}^{-1}$ ) for 15 minutes, before being rinsed with running water. The excess water was removed before the fruits were chopped, dried in an oven at $40{ }^{\circ} \mathrm{C}$ for 24 hours, and milled in an analytical mill (A 11 basic $^{\circledR}$, IKA, Germany). All the products were sieved to obtain standardized samples with 100 mesh granulometry. All samples were packed in plastic flasks which were stored away from light in a dry and cool place until use.

\section{Characterization of plant samples}

The samples of cinnamon, turmeric, and okra were characterized according to their physical and chemical compositions. All analyses were performed in triplicate. The results are expressed as mean \pm standard deviation. Determination of moisture, ash, protein, lipid, and carbohydrate content was performed according to Latimer. ${ }^{(21)}$

\section{Determination of antioxidants}

The plant samples were extracted in water and ethanol solution (1:4) for 24 hours, at $2{ }^{\circ} \mathrm{C}$. The mixture was centrifuged in a refrigerated centrifuge (5804 $\mathrm{R}^{\circledR}$, Eppendorf, Germany) under the following conditions: $4{ }^{\circ} \mathrm{C}, 1000 \mathrm{x} \mathrm{g}$, for $10 \mathrm{~min}$ utes. The extract obtained was used for the determination of antioxidants.

Total phenolic compounds were quantified using the Folin-Ciocalteau method. ${ }^{(22)}$ The absorbance reading was performed on a spectrophotometer (GENESYS 6 ${ }^{\circledR}$, Thermo Fisher Scientific, United States of America - USA) at $760 \mathrm{~nm}$. The results were expressed based on a standard curve of gallic acid, in mg of gallic acid equivalent (GAE)/g of sample. The analysis was performed in triplicate and the values expressed as mean \pm standard deviation.

The antioxidant capacity was determined using the 2,2-diphenyl-1-picrilhhydrazyl (DPPH) method. The extracts were placed in a mixture containing $0.1 \mathrm{M}$ acetate buffer ( $\mathrm{pH}$ 5.5) and an ethanol DPPH solution $(250 \mu \mathrm{M}$ in ethanol). After 15 minutes, the absorbances were read on a spectrophotometer (GENESYS $6^{\circledR}$, Thermo Fisher Scientific, USA) at $517 \mathrm{~nm}$. The antioxidant capacity was calculated in relation to the activity of 6-hydroxy2,5,7,8-tetramethylchroman-2-carboxylic acid (Trolox), based on a standard curve. The results were expressed as Trolox Equivalent Antioxidant Activity (TEAC) in $\mu \mathrm{M}$ Trolox/g of sample. The analysis was performed in triplicate and the values expressed as mean \pm standard deviation.

The determination of antioxidant capacity was based on the 2,2'-azino-bis (3-ethylbenzothiazoline6-sulfonic acid) method (ABTS). The extracts were placed in an ABTS solution in $20 \mathrm{mM}$ phosphate 
buffer ( $\mathrm{pH}$ 7.4). The absorbance reading was performed in a spectrophotometer (GENESYS $6^{\circledR}$, Thermo Fisher Scientific, USA) at $734 \mathrm{~nm}$. The antioxidant capacity was calculated in relation to the Trolox activity, based on a standard curve. The results were expressed in TEAC in $\mu \mathrm{M}$ Trolox/g of sample. The analysis was performed in triplicate and the values expressed as mean \pm standard deviation.

\section{Determination of curcumin content}

The curcumin content (\%) of the Curcuma longa sample was determined by high performance liquid chromatography. The curcumin standard used was Sigma-Aldrich ${ }^{\circledR}$, Merck, Germany, prepared in acetonitrile (J. T. Baker Chemical Company, USA) and the sample, in acetonitrile solution: ultrapure water (MilliQ ${ }^{\circledR}$, Merck, Germany) 10:90 (v/v), filtered through a $0.45 \mu \mathrm{m} \times 13 \mathrm{~mm}$ polyvinylidene fluoride (PVDF) membrane (Millipore ${ }^{\circledR}$, Merck, Germany). The instrumental system used consisted of a Shimadzu Prominence LC-20A liquid chromatograph (Shimadzu Corporation, Kyoto, Japan), consisting of a CBM-20A communication module, CTO-20A column oven, SPD-M20A diode array detector at $425 \mathrm{~nm}$, SIL-20AC HT automatic injector at $10{ }^{\circ} \mathrm{C}$, and pump with an LC-20AT quaternary phase mixer. The elution of the sample was performed using an isocratic mode with the mobile phases acetonitrile (JT Baker Chemical Company, USA): ultrapure water (MiiliQ ${ }^{\circledR}$, Merck, Germany) in the proportion 13:87 (v/v) for 15 minutes in a YMC ODS-AQ column (C18), $5 \mu \mathrm{m}, 150 \times 6.0 \mathrm{~mm}$ (Tedia Brazil, Brazil), with an injection volume of $20 \mu \mathrm{L}$ at a flow rate of $1.0 \mathrm{~mL} \cdot \mathrm{min}^{-1}$. Data acquisition and processing were performed with the aid of LC solution software (Shimadzu Corporation, Kyoto, Japan).

\section{Animals and experimental protocol}

Figure 1 shows the descriptive flowchart of the experimental design. A total of 48 male Wistar rats of 90 days of age, from the Central Vivarium at the Universidade Estadual de Londrina (UEL), Londrina, Paraná, Brazil, were randomly assigned to four groups: Control (CO), Turmeric (TU), Cinnamon $(\mathrm{CI})$, and Okra (OK), composed of 12 rats each. Before the start of the experiment, the animals were kept for 7 days in our vivarium for acclimatization under the following conditions: four animals per cage, light and dark cycle of 12 hours (light on from 7 a.m.), fed with standard rodent chow diet (Nuvilab ${ }^{\circledR}$, Nuvital, Brazil) and water $a d$ libitum, and temperature controlled at $24 \pm 1{ }^{\circ} \mathrm{C}$.

Figure 1 - Descriptive flowchart of the experimental design.

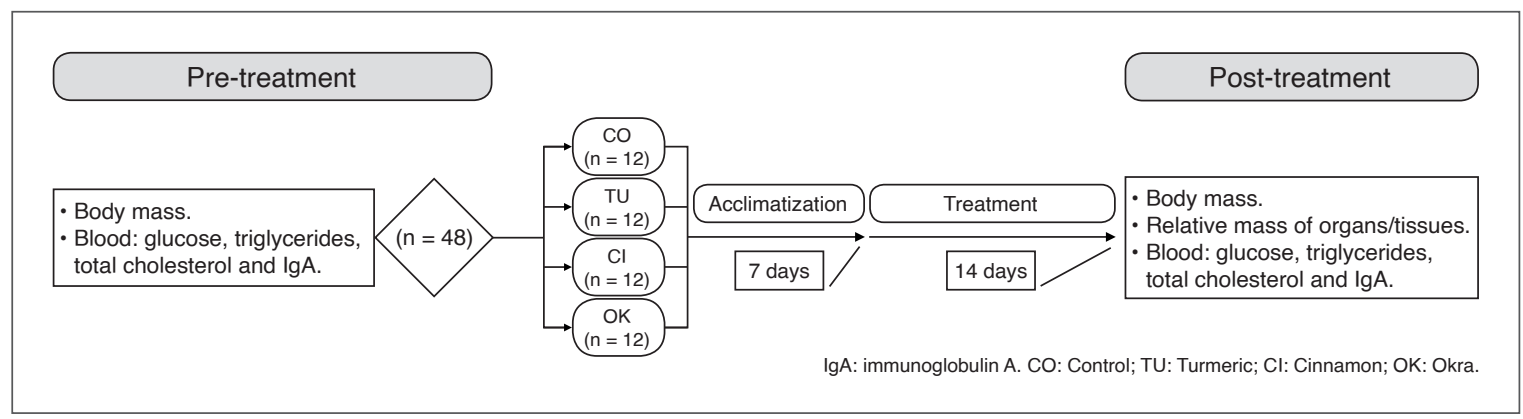

Source: the authors.

After the acclimatization period, the animals were weighed and anesthetized intramuscularly with a combination of ketamine (Dopalen ${ }^{\circledR}$, Sespo,
Brazil; $100 \mathrm{mg} / \mathrm{kg}$ ) and xylazine (Anasedan ${ }^{\circledR}$, Sespo, Brazil; $20 \mathrm{mg} / \mathrm{kg}$ ) to obtain blood samples, respecting a pre-harvesting fast of 15 hours. The animals 
were then treated daily by gavage for 14 uninterrupted days. The $\mathrm{CO}$ group received $0.5 \mathrm{~mL}$ of phosphate buffered saline (PBS), $\mathrm{pH} 7.4$, while the other groups (TU, CI, OK) received the samples (turmeric, cinnamon, and okra) prepared in $0.5 \mathrm{~mL}$ of PBS, corresponding to 50, 50, and $12.5 \mathrm{mg}$ of each product, respectively.

At the end of the $14^{\text {th }}$ day of treatment, after a pre-harvesting fast of 15 hours, the animals were weighed and anesthetized, as previously described, to obtain blood samples. The animals were then euthanized with a ketamine-xylazine overdose and dissected to obtain internal organs and tissues (peritoneal fat, adrenal gland, kidney, spleen, liver, and thymus). The organs and tissues were weighed, and the data presented as relative weight. The experimental protocol was approved by the Ethics Committee for Animal Research of the Universidade Estadual de Londrina (process number 8185.2014. 18). All efforts were made to minimize the number of animals used and their suffering.

\section{Biochemical analyses and total serum IgA measurement}

To evaluate glucose levels (mg.dL ${ }^{-1}$ ), the blood of the animals was collected by cardiac puncture in a test tube containing sodium fluoride (0.6 mg. $\left.\mathrm{mL}^{-1}\right)$ and ethylenediaminetetraacetic acid (EDTA) (2 mg. $\left.\mathrm{mL}^{-1}\right)$ before and after the treatment. The samples were then centrifuged at $1000 \mathrm{x}$ $g$ for 5 minutes. Plasma was recovered, aliquoted, and stored at $-20^{\circ} \mathrm{C}$ until analysis.

The levels of triglycerides (mg. $\left.\mathrm{dL}^{-1}\right)$, total cholesterol $\left(\mathrm{mg}^{\mathrm{dL}} \mathrm{L}^{-1}\right)$, aspartate aminotransferase (AST) (U.L ${ }^{-1}$ ), alanine aminotransferase (ALT) (U.L ${ }^{-1}$ ), and humoral immunity were evaluated in serum after blood collection by cardiac puncture in a tube free of anticoagulants, before and after the treatment. Following coagulation, the samples were centrifuged at $1000 \times g$ for 5 minutes. The serum was recovered and aliquoted and stored at $-20{ }^{\circ} \mathrm{C}$ until analysis.
Biochemical analyses were performed in a biochemical analyzer (Dimension ${ }^{\circledR}$ Clinical Chemistry System, Siemens, Germany) at the laboratory of the Veterinary Hospital of the Universidade Estadual de Londrina (HV-UEL) using available commercial kits.

Determination of IgA levels $\left(\mathrm{mg} \cdot \mathrm{dL}^{-1}\right)$ in serum was performed by indirect enzyme-linked immunosorbent assay (ELISA) using the Rat IgA ELISA Quantitation Set ${ }^{\circledR}$ quantification system (Bethyl Laboratories, Inc., USA), according to the manufacturer's specifications, with modifications. Blocking was performed with PBS containing 5\% skimmed milk (Molico ${ }^{\circledR}$, Nestlé, Brazil) and dilutions of the standard curve, samples, and conjugated antibody were performed in PBS containing 1\% skimmed milk.

\section{Statistical analyses}

The sample normality was verified using the Shapiro-Wilk test and the sample homogeneity by the Levene test. The one-way ANOVA test was performed to compare the variables between the groups in the pre- or post-intervention moment and to analyze the relative weight of the organs and tissues (differences between treatments at the same moment). In the intra-group comparisons, the paired " $t$ " test was used (differences in the same group in the pre and post intervention moments). The statistical package SPSS ${ }^{\circledR} 23.0$ (IBM, USA) was used, adopting a $P$ value $<0.05$.

\section{Results}

Table 1 presents the results of the characterization of the turmeric, okra, and cinnamon samples, regarding the physical-chemical composition, content of total phenolic compounds, and antioxidant capacity (DPPH and ABTS). Regarding the curcumin content of the Curcuma longa sample, a curcumin content of $5.1 \pm 0.1 \%$ (dry basis) was observed. 
Table 1 - Centesimal composition of cinnamon, turmeric, and okra in terms of moisture, ash, protein, lipids and carbohydrates and total phenolic compounds and antioxidant capacity.

\begin{tabular}{lccc}
\hline Variables & Turmeric & Okra & Cinnamon \\
\hline Humidity & $10.0 \pm 0.3$ & $9.4 \pm 0.3$ & $10.9 \pm 0.1$ \\
Ashes & $5.1 \pm 0.1$ & $9.4 \pm 0.1$ & $4.5 \pm 0.0$ \\
Proteins & $7.9 \pm 0.3$ & $22.9 \pm 1.9$ & $5.8 \pm 0.2$ \\
Lipids & $1.3 \pm 0.6$ & $1.1 \pm 0.0$ & $2.6 \pm 0.5$ \\
Carbohydrates* & 75.7 & 57.2 & 76.2 \\
Total phenolic compounds ** & $187.9 \pm 1.2$ & $120.5 \pm 1.8$ & $23.0 \pm 0.8$ \\
DPPH*** & $4.0 \pm 0.7$ & $2.0 \pm 0.5$ & $47.1 \pm 3.9$ \\
ABTS*** & $24.5 \pm 6.8$ & $14.7 \pm 1.8$ & $130.5 \pm 7.6$ \\
\hline
\end{tabular}

Caption: values expressed in percentages and mean \pm standard deviation; *values obtained by difference; **values expressed in $\mathrm{mg} \mathrm{GAE} / \mathrm{g}$ of sample; ***values expressed in TEAC ( $\mu \mathrm{M}$ Trolox/g of sample). DPPH, radical 2,2-diphenyl-1-picrilhidrazil; ABTS, radical 2,2'-azino-bis (3-ethylbenzothiazoline-6-sulfonic acid).

Source: the authors.

The current study showed that the addi- body mass and relative weight of adrenal gland, tion of turmeric or cinnamon (50 mg per day), spleen, liver, peritoneal fat, kidney, and thymus as well as okra (12.5 mg per day) to the conven- (Table 3, p >0.05). However, an increase in sera tional diet of healthy Wistar rats did not change IgA levels was observed in the groups of animals glucose, triglycerides, total cholesterol, liver en- treated with turmeric and cinnamon (Figure 2, zymes AST and ALT (Table 2, p >0.05), as well as $\mathrm{p}<0.05$ ).

Table 2 - Body mass, blood biochemical parameters, and IgA blood levels pre- and post-treatment.

\begin{tabular}{|c|c|c|c|c|c|c|c|c|c|c|c|c|c|c|c|c|}
\hline \multirow{2}{*}{ Variables } & \multicolumn{4}{|c|}{$\operatorname{CO}(n=12)$} & \multicolumn{4}{|c|}{ TU $(n=12)$} & \multicolumn{4}{|c|}{$C I(n=12)$} & \multicolumn{4}{|c|}{ OK $(n=12)$} \\
\hline & Pre & & Post & & Pre & & Post & & Pre & & Post & & Pre & & Post & \\
\hline \multirow{2}{*}{ Body mass (g) } & 348.6 & \pm & 357.5 & \pm & 360.1 & \pm & 364.5 & \pm & 380.3 & \pm & 351.7 & \pm & 335.2 & \pm & 347.7 & \\
\hline & 113.9 & & 116.4 & & 49.5 & & 54.1 & & 42.5 & & 118.2 & & 114.6 & & 118.4 & \\
\hline \multirow{2}{*}{ Glu (mg.dL $\left.{ }^{-1}\right)$} & 164.1 & \pm & 140.5 & \pm & 149.4 & \pm & 159.8 & \pm & 159.4 & \pm & 146.0 & \pm & 168.5 & \pm & 147.1 & \pm \\
\hline & 17.8 & & 47.0 & & 35.2 & & 25.6 & & 29.1 & & 64.4 & & 27.9 & & 61.9 & \\
\hline \multirow{2}{*}{ Tgl (mg.dL $\left.{ }^{-1}\right)$} & 89.6 & \pm & 108.5 & \pm & 79.3 & \pm & 89.6 & \pm & 80.7 & \pm & 90.7 & \pm & 76.5 & \pm & 94.2 & \pm \\
\hline & 34.8 & & 51.6 & & 41.0 & & 39.8 & & 40.1 & & 42.8 & & 48.1 & & 42.3 & \\
\hline \multirow{2}{*}{ TC $\left(\mathrm{mg.dL}^{-1}\right)$} & 68.8 & \pm & 71.9 & \pm & 62.9 & \pm & 68.7 & \pm & 71.8 & \pm & 69.4 & \pm & 66.3 & \pm & 69.0 & \pm \\
\hline & 11.3 & & 27.0 & & 12.9 & & 11.0 & & 15.1 & & 26.9 & & 11.5 & & 23.5 & \\
\hline \multirow{2}{*}{ AST (U.L-1) } & 153.2 & \pm & 136.0 & \pm & 160.0 & \pm & 135.0 & \pm & 148.5 & \pm & 181.4 & \pm & 158.3 & \pm & 132.3 & \pm \\
\hline & 26.0 & & 56.4 & & 37.9 & & 22.5 & & 56.6 & & 92.8 & & 25.1 & & 60.6 & \\
\hline \multirow{2}{*}{$\operatorname{ALT}\left(\mathbf{U} \cdot \mathbf{L}^{-1}\right)$} & 53.4 & \pm & 48.2 & \pm & 55.0 & \pm & 51.1 & \pm & 52.9 & \pm & 53.5 & \pm & 56.3 & \pm & 50.3 & \pm \\
\hline & 18.6 & & 21.3 & & 13.4 & & 12.6 & & 11.2 & & 22.5 & & 8.3 & & 18.8 & \\
\hline
\end{tabular}

Caption: groups: Control (CO); Turmeric (TU); Cinnamon (CI); Okra (OK). Values expressed as mean \pm standard deviation; Body mass: Mass, Glu: Glucose, Tgl: Triglycerides, TC: Total cholesterol, AST: Aspartate aminotransferase, ALT: Alanine aminotransferase; Pre: pre-treatment, Post: post-treatment. Values expressed as mean \pm standard deviation; one-way ANOVA and paired " $t$ " test $(P<0.05)$.

Source: the authors. 
Table 3 - Relative weight of the organs and tissues post-treatments.

\begin{tabular}{lcccc}
\hline Variables & $\mathbf{C O}(\mathbf{n}=\mathbf{1 2})$ & $\mathbf{T U}(\mathbf{n}=\mathbf{1 2})$ & $\mathbf{C I}(\mathbf{n}=\mathbf{1 2})$ & OK $(\mathbf{n}=\mathbf{1 2})$ \\
\hline Adrenal gland (g) & $0.016 \pm 0.013$ & $0.018 \pm 0.008$ & $0.015 \pm 0.013$ & $0.018 \pm 0.012$ \\
Spleen (g) & $0.145 \pm 0.055$ & $0.152 \pm 0.018$ & $0.139 \pm 0.050$ & $0.142 \pm 0.053$ \\
Liver (g) & $2.912 \pm 0.998$ & $3.072 \pm 0.346$ & $2.692 \pm 0.940$ & $2.637 \pm 0.898$ \\
Peritoneal fat (g) & $0.825 \pm 0.496$ & $0.848 \pm 0.326$ & $0.635 \pm 0.263$ & $0.735 \pm 0.341$ \\
Kidney (g) & $1.184 \pm 0.407$ & $1.180 \pm 0.208$ & $1.114 \pm 0.408$ & $1.059 \pm 0.394$ \\
Thymus (g) & $0.037 \pm 0.023$ & $0.036 \pm 0.016$ & $0.036 \pm 0.023$ & $0.031 \pm 0.024$ \\
\hline
\end{tabular}

Caption: groups: Control (CO); Turmeric (TU); Cinnamon (CI); Okra (OK). Values expressed as mean \pm standard deviation; one-way ANOVA $(P<0.05)$.

Source: the authors.

Figure 2 - Evaluation of IgA concentration in rats with different treatments. Values expressed as mean \pm standard deviation. IgA: immunoglobulin A. Pre: pre-treatment; Post: post-treatment; * indicates difference in the intragroup moments. Values expressed as mean \pm standard deviation; one-way ANOVA and paired " $t$ " test $(P<0.05)$.

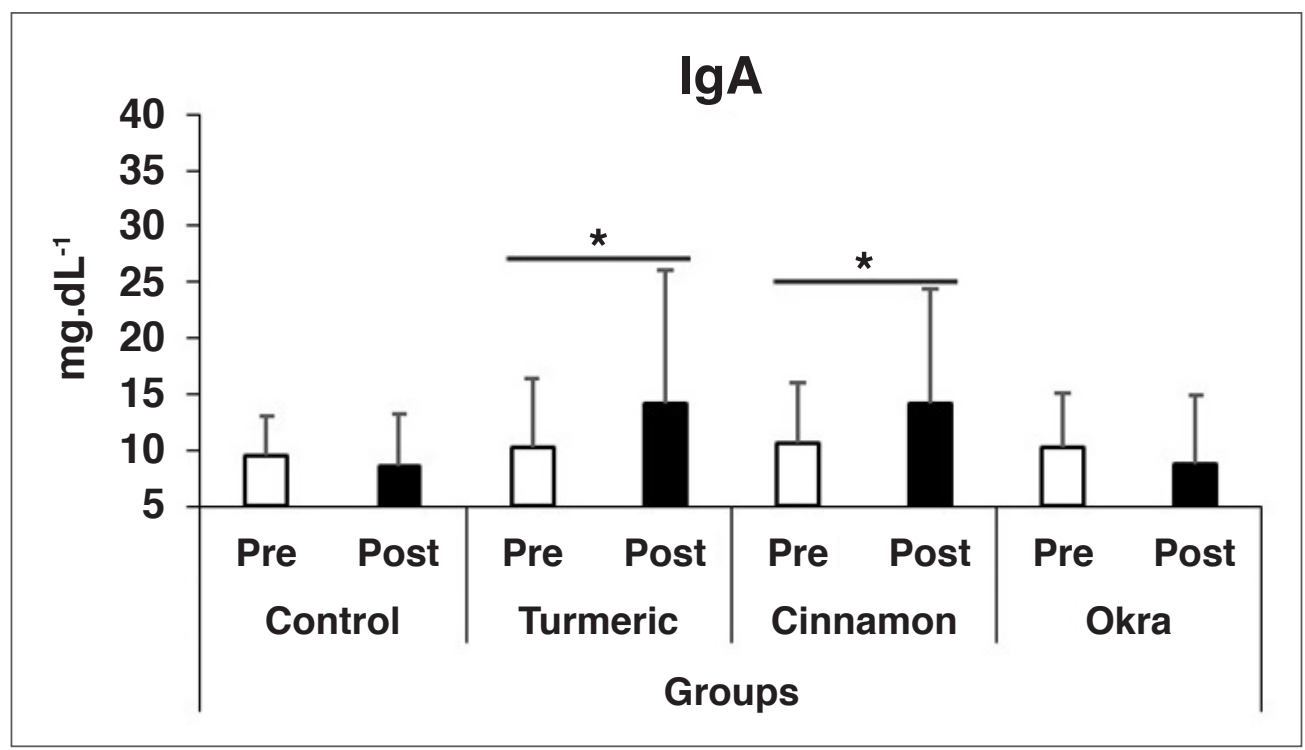

Source: the authors.

\section{Discussion}

$\operatorname{IgA}$, as the principal antibody class in the secretions that bathe these mucosal surfaces, acts as an important first line of defense. ${ }^{(23)}$ It is also an important serum immunoglobulin, which mediates a variety of protective functions through interaction with specific receptors and immune mediators, ${ }^{(19)}$ neutralizing or blocking the activity of potential opportunistic intruders without starting an inflammatory response. ${ }^{(24)}$
Turmeric is a dietary plant with an immunomodulatory effect, and in this sense, the literature has reported that it increases the intestinal immune function in high-fat fed animals by increasing IgA production or suppressing IgA degradation. ${ }^{(25)}$ This increase in IgA production was observed in animals treated with turmeric for 14 days at doses of 5 and $10 \mathrm{mg} / \mathrm{kg}$; the higher the dose, the greater the production of IgA. ${ }^{(17)}$ It is important to note that the animals treated with turmeric presented greater production of $\operatorname{IgA}$ and protection against 
Salmonella typhimurium-induced infection compared to the control. ${ }^{(26)}$

Although the mechanisms of action of turmeric in the production of $\operatorname{IgA}$ have not yet been defined, there is evidence that this may be related to curcuminoid pigments. ${ }^{(15)}$ These pigments have been shown to exhibit anti-inflammatory activity through the suppression of numerous cell signalling pathways including NF-кB, STAT3, Nrf2, and COX-2. ${ }^{(27)}$ Clinically, they have been shown to be effective against various chronic diseases, including various types of cancers, diabetes, obesity, and cardiovascular, pulmonary, neurological, and autoimmune diseases. ${ }^{(27)}$

This is the first study to find an effect of cinnamon on the production of IgA antibodies. Studies suggest that cinnamon has anti-inflammatory properties. Animals treated with cinnamon for 20 days presented a reduction in pro-inflammatory cytokines (IL-1 $\beta$, IFN- $\gamma$, and TNF- $\alpha$ ) and a significant increase in the production of anti-inflammatory cytokines (IL-10). ${ }^{(28)}$ Thus, as the importance of IL-10 in the regulation of B cell class switching has been reported in the production of $\operatorname{IgA},{ }^{(29)}$ this immunomodulatory effect could explain the fact that cinnamon elicited high IgA levels in the animals in this study.

\section{Conclusion}

The current work shows that rats fed a conventional diet with added turmeric, cinnamon, and okra did not present significant changes in body mass, relative weight of organs and tissues, and biochemical parameters. Furthermore, turmeric and cinnamon raised IgA blood levels, which may indicate immunomodulation. Although the mechanisms of action of turmeric and cinnamon in the production of IgA have not yet been defined, our study supports the idea that dietary supplementation with these plants may improve humoral immunity.

\section{Conflicts of interest}

The authors declare no conflict of interest.

\section{References}

1 Fernandes EV, Ramos AC, Santos AH, Longhini R, Gerardin DCC, Venancio EJ. Effects of maternal exposure to extract of Trichilia catigua on antibody production in the offspring of Wistar rats. Nat Prod Res. 2019;33(5):763-6. doi: 10.1080/14786419.2017.1408097.

2 Lobato LP, Fernandes EV, Juliani LC, Ferrari O, Ramos SP, Gerez JR, et al. The effects of oat bran and soy flour on humoral immune response in rats fed hypercholesterolaemic diets. Semina: Ciênc Biol Saúde. 2017;38(2): 165-74. doi: 10.5433/1679-0367.2017v38n2 p165.

3 Lai PK, Roy J. Antimicrobial and chemopreventive properties of herbs and spices. Curr Med Chem. 2004;11(11):1451-60. doi: 10.2174/0929 867043365107.

4 Eigner D, Scholz D. Ferula asa-foetida and Curcuma longa in traditional medical treatment and diet in Nepal. J Ethnopharmacol. 1999;67(1):16. doi: 10.1016/s0378-8741(98)00234-7.

5 Pierce, A. The American Pharmaceutical Practical Guide to Natural Medicines. New York: The Stonesong Press; 1999.

6 Maithilikarpagaselvi N, Sridhar MG, Swaminathan RP, Sripradha R, Badhe B. Curcumin inhibits hyperlipidemia and hepatic fat accumulation in high-fructose-fed male Wistar rats. Pharm Biol. 2016;54(12):2857-63. doi: 10.1080/13880209. 2016.1187179 .

7 Aggarwal BB, Sundaram C, Malani N, Ichikawa H. Curcumin: the indian solid gold. In: Aggarwal BB, Surh Y, Shishodia S, editors. The molecular targets and therapeutic uses of curcumin in health and disease. Switzerland: Springer; 2007. p. 1-75.

8 Jagetia GC, Aggarwal BB. "Spicing up" of the immune system by curcumin. J Clin Immunol. 2007;27(1):19-35. doi: 10.1007/s10875-0069066-7.

9 The Plant List: a working list of all plant species. [Internet]. 2013 [cited 2021 Nov 15]. Available from://www.theplantlist.org/ 
10 Gemede HF, Ratta N, Haki GD, Woldegiorgis AZ, Beyene F. Nutritional quality and health benefits of okra (Abelmoschus esculentus): a review. J Food Process Technol. 2015;4(6):20815. doi: 10.11648/j.ijnfs.20150402.22.

11 Ndjouenkeu R, Goycoolea FM, Morrisa ER, Akingbala JO. Rheology of okra (Hibiscus esculentus L.) and dika nut (Irvingia gabonensis) polysaccharides. Carbohydr Polym. 1996;29(3):263-69. doi: 10.1016/0144-8617 (96)00016-1.

12 Liu IM, Liou SS, Cheng JT. Mediation of betaendorphin by myricetin to lower plasma glucose in streptozotocin-induced diabetic rats. J Ethnopharmacol. 2006;104(1-2):199-206. doi: 10.1016/j.jep.2005.09.001.

13 Lee BJ, Kim YJ, Cho DH, Sohn NW, Kang H. Immunomodulatory effect of water extract of cinnamon on anti-CD3-induced cytokine responses and p38, JNK, ERK1/2, and STAT4 activation. Immunopharmacol Immunotoxicol. 2011;33(4):714-22. doi: 10.3109/08923973. 2011.564185 .

14 Vangalapati M, Sree SN, Surya PDV, Sumanjali A. A review on pharmacological activities and clinical effects of cinnamon species. Res J Pharm Biol Chem Sci. 2012;3(1):653-63.

15 Hewlings SJ, Kalman DS. Curcumin: A Review of Its' Effects on Human Health. Foods. 2017;6(10). doi: 10.3390/foods6100092.

16 Deyno S, Eneyew K, Seyfe S, Tuyiringire $\mathrm{N}$, Peter EL, Muluye RA, et al. Efficacy and safety of cinnamon in type 2 diabetes mellitus and pre-diabetes patients: A meta-analysis and meta-regression. Diabetes Res Clin Pract. 2019;156:107815. doi: 10.1016/j.diabres.2019. 107815 .

17 Al-Taee MF, Al-Ahmed HI, Malek HWA. Studying the effect of aqueous extract from Curcuma longa on some parameters of cytogenetic, immunity and fertility in female mice. Baghdad Science Journal. 2011;8(1):73-80. doi: 10.21123/bsj.8.1.73-80.

18 Munn EA, Feinstein A, Munro AJ. Electron microscope examination of free IgA molecules and of their complexes with antigen. Nature. 1971;231(5304):527-9. doi: 10.1038/231527a0.

19 Woof JM, Kerr MA. The function of immunoglobulin A in immunity. J Pathol. 2006;208(2): 270-82. doi: 10.1002/path.1877.

20 Wang K, Li M, Wen X, Chen X, He Z, Ni Y. Optimization of ultrasound-assisted extraction of okra (Abelmoschus esculentus (L.) Moench) polysaccharides based on response surface methodology and antioxidant activity. Int J Biol Macromol. 2018;114:1056-63. doi: 10.1016/j.ijbiomac.2018.03.145.

21 Latimer G Jr, editor. Official Methods of Analysis of AOAC International. $21^{\text {st }}$ ed. Rockville: AOAC INTERNATIONAL; 2019.

22 Lamuela Raventós RM. Folin-Ciocalteu method for the measurement of total phenolic content and antioxidant capacity. Measurement of Antioxidant Activity \& Capacity: Recent Trends and Applications. 2018:107-17. doi: 10.1002/9781119135388.ch6.

23 Pabst O, Slack E. IgA and the intestinal microbiota: the importance of being specific. Mucosal Immunol. 2020;13(1):12-21. doi: 10. 1038/s41385-019-0227-4.

24 Sousa-Pereira P, Woof JM. IgA: Structure, Function, and Developability. Antibodies (Basel). 2019;8(4):57. doi: 10.3390/antib8040057.

25 Okazaki Y, Han Y, Kayahara M, Watanabe T, Arishige H, Kato N. Consumption of curcumin elevates fecal immunoglobulin $\mathrm{A}$, an index of intestinal immune function, in rats fed a high-fat diet. J Nutr Sci Vitaminol (Tokyo). 2010;56(1):68-71. doi: 10.3177/jnsv.56.68.

26 Kim SP, Lee SJ, Nam SH, Friedman M. Turmeric bioprocessed with mycelia from the shiitake culinary-medicinal mushroom Lentinus edodes (Agaricomycetes) protects mice against salmonellosis. Int J Med Mushrooms. 2017;19(4):363-76. doi: 10.1615/IntJMedMushrooms.v19.i4.70.

27 Kunnumakkara AB, Bordoloi D, Padmavathi G, Monisha J, Roy NK, Prasad S, et al. Curcumin, the golden nutraceutical: multitargeting 
for multiple chronic diseases. Br J Pharmacol. 2017;174(11):1325-48. doi: 10.1111/bph.13621.

28 Kwon HK, Hwang JS, Lee CG, So JS, Sahoo A, Im CR, et al. Cinnamon extract suppresses experimental colitis through modulation of antigen-presenting cells. World J Gastroenterol. 2011;17(8):976-86. doi: 10.3748/wjg.v17.i8.976.

29 Bagheri Y, Babaha F, Falak R, Yazdani R, Azizi G, Sadri M, et al. IL-10 induces TGF- $\beta$ secretion, TGF- $\beta$ receptor II upregulation, and IgA secretion in B cells. Eur Cytokine Netw. 2019;30(3):107-13. doi: 10.1684/ecn.2019.0434. 